\title{
States, Mining Companies and State Corporations: a Review Article
}

Mike Faber

Outlook for Mineral Commodities, by R. H. Carnegie, Group of Thirty, New York, 1986.

Options for Developing Countries in Mining Development, by G. W. Walrond and R. Kumar, Macmillan, 1986.

State Mineral Enterprises - An Investigation into Their Impact on International Mineral Markets, by M. Radetzki, Resources for the Future, Washington, 1985.

Mining Taxation in the ESCAP Region: Review and Proposals for Reform, by R. Garnaut and C. Emerson, ESCAP/CTC, New York, 1985.

In the years immediately following their independence, the governments of many developing countries viewed with suspicion, and even hostility, the operations within their territories of the multinational corporations (MNCs). Amongst such MNCs, none were viewed with greater suspicion than those involved in mining. Mining is a business which often gives rise to rough expressions of emotion - irreplaceable natural resources are being extracted, large investments are made, numerous and highly organised work forces are involved, the pricing of the product is uncertain and transfer pricing often suspected. Charges of 'exploitation' come easily to the throats of local factions and, if because the resources are exhausted or for reasons of low prices, the mine and its associated plant have to shut down, large numbers of workers will be rendered unemployed - of ten in remote areas where alternative employment is not in prospect.

Such potent mixtures of motives led to the establishment of mineral state enterprises in many developing countries soon after their independence. Control over the strategic heights of the economy: the need to learn the business: localisation of management and employees: maximisation of revenues and foreign exchange earnings - all these, as well as suspicion and hostility could be cited as reasons. Appraised in comparative tranquillity, the experience of the past 20 years with operations of state mineral corporations should enable us now to identify more clearly what in practice were their goals and their achievements. Have they served the purposes which developing country governments had in mind for them? Or have they been costly and inefficient failures? Or have they achieved some objectives but only at the expense of others? Or are we in a position to say, as Rod Sims (1985) has argued in a recent issue of Natural Resources Forum, ${ }^{1}$ that other mechanisms (such as progressive participation arrangements and new forms of taxes and royalties) now enable host country governments to achieve those that were ever realistic amongst those original objectives in a safer and more effective way?

Or perhaps expropriations and nationalisations of enterprises in the mining sector occur in waves - a spate of them when prices are high or immediately after independence, followed by a slackening off and even some privatisation as disillusionment with the conduct of parastatals becomes more widespread? Or could there be other reasons for the apparent spirit of reconciliation between government and the mining MNCs which is now apparent in several developing countries?

The four publications discussed here fit neatly together. Carnegie in Outlook for Mineral Commodities looks at how the location of the mining and processing of the world's leading non-ferrous metals has changed over the past 20 years and speculates as to how those changes may continue in the future. The conclusion is that the developing countries are likely to increase

\footnotetext{
1 'Government Ownership Versus Regulation of Mining Enterprises in Less-developed Countries' by Rod Sims, in Natural Resources Forum Vol. 9, No. 4, November 1985, pp 265-282.
}

IDS Bulierin. 1986. vol 17 no 4, Institute of Development Studies. Sussex 
their proportionate share of production, processing, fabricating and trade in most of such minerals. Walrond and Kumar, as their title indicates, look at the Options for Developing Countries in Mining Development, although their treatment is not as consistently wide as this might suggest. Radetzki looks in detail at one such option, namely the creation of 'State Mineral Enterprises' but argues that this particular form, although much used in the 1960s and 1970 s, may not spread as rapidly in future. The Garnaut and Emerson report contains a scholarly analysis of the taxation regimes in an area where mineral production is likely to go on expanding.

This review article proceeds as follows. I summarise Carnegie's argument in order to set the scene. Walrond and Kumar's 'Options' are considered in somewhat more detail, as much to survey the contents of their book as to weigh the merits of the different policies available. The bulk of the article is given over to considering Radetzki's appraisal of the performance and prospect of mining parastatals. In looking at the Garnaut and Emerson report I consider whether Radetzki's analysis - if accepted - might lead to a wider adoption of their own proposals.

\section{Carnegie's Outlook for Mineral Commodities}

Sir Roderick Carnegie is chairman of the Australian mining giant ConZinc-Rio Tinto of Australia CRA. ${ }^{2}$ His study for the Group of Thirty looks at how the location of mineral production, smelting, refining and fabricating has been shifting and discusses what further shifts may be anticipated in the future. Between 1965 and 1980, developing countries succeeded in increasing their share of world mine production of copper, iron ore and nickel, held onto their shares of lead and zinc production and suffered a decline in market share only in bauxite - largely because of the massive increase in Australia's market share. Carnegie's expectation is that these trends will continue, with OECD production (other than in Canada and Australia) tending to be replaced by that from developing countries. My own rider to that proposition would be that if growth in world output is slow the rate of change in market shares will also be slow, particularly if the use of scrap is taken into account. It is only if the demand for minerals increases enough for the opening of a substantial number of new mines to be required that we will see a significant rate of change in market shares.

Table 1, containing figures adapted from World Bank sources shows how percentage shares in total world mine production has changed for six major minerals

\footnotetext{
2 CRA is 52.3 per cent owned by RTZ, but the British company has agreed to reduce its holding in CRA to below 50 per cent sometime in the future.
}

between 1965 and 1980 and provides an estimate of projected shares for 1995 .

But these are not the only changes that Carnegie foresees or postulates. Because of their relatively unadvanced and simple economic structures, a given rate of growth in output within developing countries gives rise to a significantly faster rate of growth in demand for minerals and metals than would occur in a more industrialised economy. Developing countries are therefore likely to become not only greater producers of minerals, but greater consumers of them as well. Indeed the second process will help to fuel the first. It will also encourage (and assist) developing country governments to take measures that will locate more of the smelting, refining and even fabricating within their own economies. They will thus hope to capture more of the downstream 'value added' from mineral production as well as enhancing employment and the development of skills.

Three other changes will surely occur in time, although it may be questioned to what extent they will come about by 1995. There seems no reason to suppose that some of the major Third World mining enterprises will not themselves develop into strong multinationals. A second change could involve a shift in the control of the trade and transportation of minerals. And a third must - in time - see a reform (and, one hopes, an improvement) in the way in which minerals and metal are priced. It is 20 years since I first heard wild-eyed Professor Mars propound his scheme for a CIPEC 'Virgin Metal Exchange' to replace the LME, with information on bargains being bounced around the world off satellites and prices being flashed up simultaneously on large screens in Lusaka, Kinshasa, Santiago and Lima. Any such scheme seems further away today than it did in 1965. But every time I accompany a group of developing country visitors to the LME so that they can learn how their copper contracts get priced, I come away with the feeling that however valid the system might be for equating demand and supply in a residual market, it is not one producers are likely to tolerate forever for the pricing of their major export.

\section{Walrond and Kumar's Options for Developing Countries}

The book by Walrond and $\mathrm{Kumar}^{3}$ is the latest of the 30 or so contributions on this subject made by those who have worked with the Technical Assistance Group (TAG) of the Commonwealth Secretariat. Aspects or ingredients of "the Commonwealth Regime' now feature in the mining codes and taxation arrangements of many countries around the world, not just those within the Commonwealth.

${ }_{3}$ This part of this article has been adapted from a book review prepared for the Journal of Development Studies. 
Percentage shares in total mine production

(tons of contained metal) by economic regions

\begin{tabular}{|c|c|c|c|c|c|c|c|c|c|}
\hline & \multicolumn{6}{|c|}{ Actual } & \multicolumn{3}{|c|}{ Projected } \\
\hline & \multicolumn{3}{|c|}{1965} & \multicolumn{3}{|c|}{1980} & \multicolumn{3}{|c|}{1995} \\
\hline & $I$ & $D$ & $C P$ & $I$ & $D$ & $C P$ & $I$ & $D$ & $C P$ \\
\hline Copper & 39 & 45 & 16 & 31 & 49 & 20 & 25 & 51 & 24 \\
\hline Lead & 46 & 34 & 21 & 45 & 33 & 21 & 43 & 35 & 22 \\
\hline Zinc & 57 & 27 & 16 & 50 & 28 & 22 & 51 & 29 & 20 \\
\hline Iron Ore & 44 & 29 & 27 & 34 & 38 & 28 & 28 & 42 & 30 \\
\hline Bauxite & 16 & 67 & 17 & 34 & 55 & 11 & 32 & 56 & 12 \\
\hline Nickel & 70 & 9 & 21 & 47 & 30 & 23 & 40 & 37 & 22 \\
\hline
\end{tabular}

I - Industrial economies; D - Developing economies; CP - Centrally planned economies

Source: adapted from World Bank

The book itself lies somewhere between a textbook for students and a handbook for practitioners. Its earlier sections deal with the organisation and administration of the mining sector - by which is meant the regulatory system designed to cover the full sequence of reconnaissance, exploration, prospecting, mine development and mining operations for both large mines and small and for a range of different minerals. The middle sections deal with the design and administration of different fiscal and financial regimes and discuss the purpose and merits of the various charges that may be levied. The underlying assumption in these sections is that the principal economic justification for the various levels (of charges) is to capture the bulk of the resource rent generated by (the resource's) exploitation, but without affecting operational efficiency or discouraging investment'. One whole chapter in this section is devoted to an analysis of the impact of different regimes (where a regime is understood to be composed of a combination of different financial charges) upon mines displaying different characteristics by means of the use of computer models. A third section deals with the issues that are likely to arise in the negotiation of mineral development agreements, and this is followed by a brief summary and conclusions. What enriches the discussion - and renders it more useful to the practitioner - is that virtually every issue is illustrated by reference to the administrative provisions and regimes prevailing in eight different countries, namely Sierra Leone, Tanzania, Zambia, Botswana, Papua New Guinea, Perak (Malaysia), Quebec (Canada), and Western Australia.

For the developed countries with which they are concerned - most of them, it will be noted, the smaller ones - Walrond and Kumar assert that 'the joint-participation approach' between a foreign investor (or operator) and the host country government (or other local interests) has become 'the dominant trend' and their guide book seems to assume that this will (and probably should) continue to be the case. Often, of course, the domestic participation will be through a state mineral enterprise of the kind described and analysed by Radetzki. There is a further assumption that any major mineral project will require the negotiation of a special agreement, but that any such agreement should fit into a carefully prepared legal framework with the values of only a limited number of chosen variables being negotiable in respect of a specific project. The authors have some wise words to say about such negotiations and on how most pragmatically to interpret the sensitive issue of sovereignty over mineral resources:

'The negotiation process is just the beginning, and perhaps the easiest part of the whole project cycle. The state must develop its own capability through its tax authorities, mining administration, training and business acumen, to first monitor the activities of the company and then, more importantly, to engage in true partnership, as among equals ... Sovereignt y should then best be const rued in terms of the state's ability to manipulate the conversion of the nation's resources into growth and development...' 


\section{Radetzki's State Mineral Enterprises}

Let us approach Radetzki by way of his conclusions. These he presents as being 'a set of plausible hypotheses that have been derived from general empirical observation and economic analysis and that are supported by the case study material but that remain to be formally validated'. The conclusions are five. First conclusion; that the widespread nationalisations of recent decades have reduced mineral output and raised prices compared to what would have prevailed under uninterrupted private $\mathrm{MNC}$ regimes, but that this market impact should diminish as stateowned firms gain experience. The transition process, however, may take 10-20 years in individual cases. Second conclusion; that the takeover by state enterprises does permanently raise production costs, because their managements are under less pressure to keep costs down and because of the pursuit by such mining parastatals of certain social objectives, often rather muddled in their definition. For the richer mines, these tendencies will absorb part - possibly a major part - of the mineral rent. For the more marginal ventures, it is likely to mean that the state enterprise will need regular subsidies. Third conclusion; that the increasing importance of state-controlled ventures in Third World mining is likely to result in greater medium-run price instability because state firms are less flexible in adjusting capacity utilisation, especially downwards, to cyclical variations in demand. Fourth conclusion; nationalisations have permanently reduced the degree of vertical integration in the production, processing and trading in most mineral products. The consequent broadening of the arms-length markets for such products should contribute to price stability in the non-captive trade even if individual firms henceforth suffer from greater revenue instability. Fifth conclusion; the private sector's share of world markets in the minerals under study has shrunk and may shrink even more but it is unlikely to disappear (and may even recover) (i) because the fashion for Third World nationalisations (and the reasons for them) seem to be on the decline; (ii) because parastatals' operations and investments are less cost-efficient than those of the private sector; (iii) because governments' taste for (and ability to offer) endless subsidies seems to be on the wane; and (iv) because governments' ability to raise finance for further investment in mineral production in the medium future may be even more constrained than that of the private sector.

There is thus plenty there to get one's teeth into. So let us go back and look at Radetzki's evidence and method. The book starts with the undeniable assertion that since the 1950 s state ownership of developing countries' metallic mineral industries has undergone a sizable expansion. Forty years ago government equity holdings in such industries were insignificant; today, such holdings constitute about half the metallic mineral production capacity in the Third World. The minerals with which the book is concerned are copper, bauxite/alumina/aluminium, iron ore, tin (which four minerals together comprise two-thirds of the value of all metal minerals in the world economy), lead and zinc, cobalt, chromium and molybdenum - nearly all of them industries in which a high degree of obligopoly has customarily prevailed in the sense that, at least at the processing stage, the largest ten companies in each industry have controlled anything from 50 per cent to 97 per cent of Western world capacity (p5). One of the more interesting, but perhaps more questionable assumptions that Radetzki makes is that as state enterprises in the mineral sector become more experienced they will tend to reproduce the same degree of 'producer coordination' that characterised the industries when they were dominated by a handful of the larger multinational corporations.

Table 2 here reproduces (in abbreviated form) data which Radetzki displays to illustrate the degree of developing government ownership in three major mineral industries in 1981. For bauxite, LDC capacity constituted 58.4 per cent of total 'western world' capacity in that year. For copper, the comparable figure was 52.7 per cent. For iron ore, the actual production in 1981 was 40.0 per cent of 'western world' production ( $\mathrm{p} 20)$. The table is suggestive in other ways. It shows that the nearer one gets to the market, the greater the proportion of capacity tends to be controlled within consumer countries. It also shows how successful (if that is the right word) the big five in the aluminium industry have been in separating the control of alumina production from that of either bauxite mining or of the smelting of aluminium.

A chapter of Radetzki's book is devoted to 'Motivations for Establishing State Mineral Enterprises' but such motives may be presumed to be familiar to Bulletin readers. More interesting are the lists of particular mining companies throughout the western world with significant government ownership and the three case studies (tin in Indonesia; iron ore in Venezuela; copper in Zambia) which comprise the latter part of the book. The growth to predominance of state controlled capacity in LDC mining has resulted from the combination of three different series of events. These have been (i) the nationalisations or partial nationalisations - of (usually foreign owned) private firms, often by recently independent governments; (ii) the expansion of capacity by existing statecontrolled companies, and (iii) substantial government participation in joint ventures with mining multinationals in the development of new capacity.

Consideration of these series of events - and analysis 
Government Ownership Positions in Three Major Mineral Industries 1981

\section{Aluminium

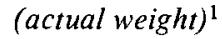 \\ Copper \\ (metal content) \\ Mining Refining Smelting Mining Smelting Refining (actual weight)}

\begin{tabular}{|c|c|c|c|c|c|c|c|}
\hline Developing Countries & & & & & & & \\
\hline Total capacity (000 tons) & 54,000 & 6,530 & 2,190 & 4,120 & 3,340 & 2,580 & 216,900 \\
\hline $\begin{array}{l}\text { Per cent of capacity with } \\
\text { significant government } \\
\text { ownership }\end{array}$ & 71.1 & 54.9 & 60.3 & 73.0 & 75.5 & 82.6 & 94.7 \\
\hline $\begin{array}{l}\text { Per cent of equity held by } \\
\text { government }\end{array}$ & 41.1 & 21.1 & 44.7 & 57.8 & 64.0 & 67.6 & 61.8 \\
\hline $\begin{array}{l}\text { Per cent of capacity with } \\
\text { majority government } \\
\text { ownership }\end{array}$ & 33.3 & 12.3 & 45.6 & 62.0 & 72.9 & 77.0 & n.a. \\
\hline
\end{tabular}

${ }^{1}$ Figures for aluminium are for 1980

${ }^{2}$ Figures for iron ore are based on production and not on capacity

${ }^{3}$ Defined as 5 per cent and upwards of total equity

of what caused them - leads Radetzki guardedly to suggest that 'the fast-growth phase of state-ownership' may now have come to an end. He cites as reasons 'the major adjustments to rectify unfavourable colonial conditions (have) been completed', 'socialist leanings in developing countries appear less in vogue' and 'pragmatism has taken precedence over ideology'. If these judgements are correct, what we are likely to see in the next phase is a maturing in the conduct of state-owned enterprises (i.e. greater professional and technical competence internally and acting externally more like the old-fashioned companies), a greater role for national, indigenous private ownership, and amicable joint-venture arrangements between LDC governments and those old black-and-white-era villains, the mining MNCs, in the development of new projects or perhaps even in the management of existing ones.

Radetzki's method involves him next in identifying the specific characteristics which are likely to characterise state mineral enterprises ('a difference between the average private firm and the average state enterprise does exist and can be identified' (p38)), then examining the behavioural consequences of those characteristics and in particular the likely impact of that behaviour on international mineral markets. On the characteristics of state enterprises he generalises as follows: (i) goals are likely to be less clearly specified than is usual with private enterprise because the multiple objectives of state-owned firms reflect conflicting public needs and political pressures;

(ii) there is likely to be 'a hazy relationship' between top management and owners which is likely to assure management of tenure - even if it is not efficient - unless the managers fall out of political favour or break some bureaucratic rule;

(iii) state enterprises operate under less stringent with financial constraints than is usual private firms and have commonly had access to capital on advantageous terms;

(iv) state enterprises have - in government - a saviour of last resort that will come to rescue them in circumstances in which a private firm would either be taken over or would have to go out of business.

These generalisations will be recognised as being fairly standard conclusions from burgeoning literature about state enterprises that has come out of the United States in the last few years. They lead onto 'behavioural patterns typical of state enterprises' which are equally standard, indeed at this stage Radetzki purports to be doing no more than surveying the economic literature. Such patterns include substantial managerial discretion in delineating 
enterprise goals, low pressure to minimise enterprise costs, bureaucratic organisation, high capital intensity, and over-investment in capacity. Broadly, however, it can be said that Radetzki's own observations and his case studies tend to confirm the appositeness of the characteristics and behaviour patterns of state enterprises that the American literature has identified.

\section{Private and State Enterprises Contrasted}

From here it is but a few short steps to the conclusions which I summarised at the beginning of this review. But not all the steps are easy ones. There is a fairly detailed comparison made of how a foreign private sector firm may be expected to act by contrast with a state-owned mineral enterprise, and I have thought it convenient to encapsulate these comparisons in the following Table of Contrasts.

\section{TABLE OF CONTRASTS}

\section{Private Multinational will:}

a. have inefficiency limited by owners;

b. exhibit capacity utilisation which will be high in booms, low in slumps;

c. behave oligopolistically, e.g. collude with rivals;

d. have investments constrained by financial capacity;

e. use high proportion of equity finance which is vulnerable to expropriation, nationalisation, spoliation, etc.;

f. rate investments by post-tax DCF;

g. favour wide geographical spread;

h. upgrade prospect if it promotes vertical integration;

i. downgrade prospects (or even ignore them) for reasons of 'political risk'.

\section{State Enterprise will:}

a. have inefficiencies much less curtailed;

b. be much less flexible in adjusting capacity utilisation;

c. collude less than the MNCs, although this may change as parastatals get more 'mature';

$\mathrm{d}$. in the past, have found finance easier and cheaper, but $3 \mathrm{~W}$ debt problem may change that;

e. use more loan finance which, in the past has not usually been valuable to repudiation etc.;

f. rank investments by social DCF returns which give more weight to forex earnings, employment creation, use of local inputs, regional balance, environmental protection;

g. concentrate exploration and investment in own country;

h. probably be less concerned with integration;

i. ignore political risk considerations ('You don't protect yourself against yourself').
A number of other ingredients have to be stirred into this mixture. One is the familiar - and fraught argument concerning the extent and quality of exploration undertaken by state enterprises. Radetzki quotes Giraud as having shown that state enterprises spent much less than private firms on mineral exploration in the 1970s but argues that this may have been partly compensated for by exploration in developing countries undertaken by other agencies, such as the UN Revolving Fund. The quality issue ("The mine-finder is a very exceptional animal who will not work for bureaucracies') is not extensively discussed. A second ingredient is whether it is safe to assume for the purposes of Radetzki's analysis that 'inexperienced' state mineral firms - mainly those that have taken over existing industries by nationalisation and then shown their inexperience by running them inefficiently - will eventually grow into 'mature' state enterprises, and so behave like them. Radetzki assumes that they will, but other hypotheses could also be formulated. There is a distinction too between parastatals which are managed badly, and those which perform badly because the entire economy in which they are operating is in disarray. That can be a relevant factor also in trying to assess future behaviour.

In assessing the impact upon international markets of the proliferation of Third World state mining organisations, it should be obvious that not all the 
factors noted in our 'Table of Contrasts' operate in the same direction. In particular there are two issues upon which the judgement that one arrives at must depend upon the weight accorded to the different factors and these, of course, may change over time. The first issue is whether the disregard by state enterprises of fiscal burdens and political risks in their assessment of likely returns from potential projects implies that state ownership will lead to a shift of investment flows towards those mineral-rich developing countries which the mining MNCs have tended to avoid recently because of severe fiscal regimes or perceived political risk. On this point, Radetzki limits himself to observing that this will only happen "if the increase in perceived returns resulting from the state enterprises' method of evaluating projects exceeds any possible reduction in returns [surely he means any assessed reduction] due to less efficient management of exploration programmes and higher costs of operating mineral ventures that are typical of publicly owned firms'. (Note how what was earlier an hypothesis about inefficiency has by p 58 become an assertion!)

The second unresolved issue concerns whether the unwillingness of the state-owned sector to cut capacity utilisation in response to declines in demand will or will not outweigh the price-stabilising effects of widening the market. Radetzki himself is shrewdly agnostic on this point, seeming to suggest that in order to given an answer about the past a complex econometric analysis would be needed for which data in usable form do not exist - and even then that the answer obtained might not be a safe guide to the future. He does however quote some interesting studies and figures. The study (by L. S. Powers, 'Instability in the Copper, Aluminium, Tin, and Iron and Steel Markets' published in Materials and Society, no 3, 1981) concludes that developing countries on average have been somewhat more stable (i.e. less flexible) than industrialised countries in their output of copper, aluminium, tin and iron/steel in the 195077 period. The trouble with that evidence, as Radetzki points out, is that some of the curtailments in developing country production that may have seemed statistically to have contributed to that stability (i.e. the falls in production in Zambia and Zaire) were not intended by government policy at all.

The figures that I found interesting relate to the response of different groups of copper-producing countries to major changes in the copper price in the years between 1950 and 1974. The average copper price in the 1964-74 period was (we are told) $\$ 1.85 / \mathrm{lb}$ (in constant 1981 dollars), 60 per cent above the $\$ 1.15 / \mathrm{lb}$ average for the preceding $1 \mathrm{l}$ years. During the period 1950-60 while the price was comparatively low, the four CIPEC countries (Chile, Peru, Zaire and Zambia) expanded their production on average by
6.2 per cent a year. During the period 1960-74, while prices were much higher, the same four countries' average annual rate of increase fell to 2.7 per cent. Meanwhile, western world output outside CIPEC rose by an annual average of 3.6 per cent during the earlier period and by an annual average of 4.7 per cent over the later period. Radetzki concludes from this that the exceptionally high copper prices in the 1964-74 period 'can be ascribed in some degree to the inability of Chile, Peru, Zaire and Zambia to expand capacity after partial or total nationalisations'. It could also be argued, apropos the earlier point, that the nationalisations diverted investment away from the countries where those nationalisations had occurred, although that is to imply that investment per se is the main determinant of trend output, which may not always be the case.

\section{Garnaut and Emerson on Mining Taxation in the ESCAP Region}

The Garnaut/Emerson study, like that by Walrond and Kumar, looks at the taxation applicable to mining in four countries in the ESCAP region (Australia, Indonesia, Papua New Guinea and the Philippines) and also appraises the respective regimes partly by way of applying them to four simulated operations. Beyond that, the differences between the two studies are more significant than the similarities. Garnaut/Emerson are more detailed, more academic and more thorough. Apart from describing optimality in terms of encouraging mineral investment and maximising government's share of mineral rents, the study investigates several more detailed criteria, noticeably neutrality and likely stability. Their work explicitly covers oil field operations, which the other three studies largely exclude. And the study contains a strong advocacy for the resource rent tax (RRT). This is a tax on cash flows generated by a project above a specified internal rate of return, forms of which have been adopted successfully, notably in Papua New Guinea.

Discussion of the merits and possible drawbacks of the RRT would be out of place here. The couple of pages that Walrond and Kumar devote to this form of tax (pp52-3) seem to me sensible, as are the comments made by Thomas Walde in the first issue of the Foreign Investment Law Journal (ICSID Review). My own belief is that, ex post facto, the impositions on a successful mine (or oil well) should approximate the total rental charges achieved by an appropriately designed and valued RRT, and that the intending investor should be able to see that that will be the case. But that is not the same thing as relying too heavily upon the RRT as the main means of collection. As I have argued elsewhere, there is much to be said for a combination of (i) light royalties to catch the poorly 
profitable projects - partly on the grounds that some payment should be made for the alienation of the resource; (ii) income tax and carried interest (as a form of participation) to catch projects in the middle range; and (iii) the RRT to give government a fair share in the bonanzas, whether these occur from exceptionally rich deposits or from exceptionally high prices, and as a form of ensuring the stability of the whole bargain. And if the project needs an enhanced cash flow in its early years, like Walrond and Kumar, I believe that the best form of concession to offer is accelerated capital allowances. But these are all matters for a debate that has a lot of running in it yet.

\section{Conclusion}

It is 22 years since I first got into the business of trying to restructure the basis upon which major expatriate mining corporations operate in developing countries. Reading these works provokes in me some reflections as to how the game has gone so far. Not as well as it might have done, but still not too badly. There have been profound changes in the relationships between mining MNCs and host country governments - both necessary and inevitable after independence. There have been extensive changes in many countries to the legal framework within which mining operations take place. There have been improvements - for which the Commonwealth Secretariat's Technical Assistance Group deserves part of the credit - in the technical design of mineral concession agreements and their accompanying participation and fiscal regimes. Some mining MNCs have decided that there are parts of the world where they will not operate - save perhaps as managers for a fee - understandably so in view of their experience, but that is a phase that appears likely to pass, indeed is passing already as host country governments and the MNCs learn better both what each has to offer the other and the imperatives to which each also has to respond. For many, a promising revival now awaits nothing so much as a substantial recovery in demand and prices.

What can we say with confidence in answer to those questions with which we prefaced this review? Many parastatals - perhaps most in the mining sector have not fulfilled the hopes and expectations that governments have placed in them. In part that has been luck; in part that has been due to the weaknesses in organisation and in the definition of operational objectives that Radetzki has drawn attention to; in part it has been the consequences of misguided policy directives from controlling ministries, inappropriate tax structures imposed by treasuries, and the exigencies occasioned by surrounding national economies in a state of decline or even disintegration. Indigenisation of management may well have been achieved more rapidly than otherwise would have been the case, but the costs in terms of lost production and profit seem sometimes to have been rather high, a form of subsidisation of the new privileged classes by those for whose benefit any additional revenues could otherwise have been spent. Where equity has been purchased with funds raised by variable rate loans and, subsequently, mineral production and prices have come down while interest rates have gone up - what might have seemed like reasonable commercial transactions at the time, from the point of view of government, have now turned out to be all too of ten, ex post facto, transactions which can be seen to have had a negative present value.

There is one other cautionary lesson that arises from the argument advanced by Rod Sims. Sims is almost certainly right in claiming that modern progressive tax systems which capture for government a major share of the resource rent are more effective in simple revenue raising terms than most state mineral corporations have been. But therein lies a danger. It is in the nature of such systems that they are highly geared to profitability - in other words when prices and profits are high the revenue yield is very good indeed - but when profits drop back revenues fall very much more than proportionately. Given the inclination of governments to allow expenditures to rise up to the level of revenue, even in good times, RRT-type systems can confront governments with an almost impossible task of expenditure contraction when mineral prices fall. Failure to achieve such contraction is likely to result in government deficits, increased borrowing, excessive credit creation, overvalued exchange rates and that whole familiar range of problems. The lesson is that RRT-type systems must be accompanied by a form of mineral revenue equalisation reserve fund to even out the flow of funds available to central government. One of the reasons why Zambia has had much greater problems in achieving stabilisation than Papua New Guinea is precisely because Zambia omitted to create such a fund whereas Papua New Guinea did so. 


\section{Books Received}

Gwendolyn Cartledge and JoAnne Fellows Milburn (eds.), Teaching Social Skills to Children, Pergamon, New York, 1986

Mahdi Adamu and A. H. M. Kirk-Greene (eds), Pastoralists of the West African Savanna, Manchester University Press, 1986

Clive Hamilton, Capitalist Industrialisation in Korea, Westview, Boulder (Co.) 1986

Parathasarathi Shome (ed.), Fiscal Issues in South-East Asia, Oxford University Press, Singapore, 1986

Michael Hubbard, Agricultural Exports and Economic Growth, KPI, London, 1986

Colin Relf, Scrap Metal Recovery: an experience of intermediate technology in Papua New Guinea, IT Publications, London, 1986

M. J. Eden and J. T. Parry (eds.), Remote Sensing and Tropical Land Management, John Wiley, Chichester, 1986

D. Dewar, A. Todes and V. Watson, Regional Development and Settlement Policy, Allen \& Unwin, London, 1986

Paul Richards, Coping with Hunger, Allen \& Unwin, London, 1986

Women in Nigeria Editorial Committee, Women and the Family, CODESRIA, Dakar, 1985

Department of Technical Cooperation for Development, Economic Performance of Public Enterprises: Major Issues and Strategies for Action, UN Development Administration Division, New York, 1986

World Resources Institute/IIED, World Resources 1986. Basic Books Inc., New York, 1986
W. A. Ndongko (ed.)., Economic Cooperation and Integration in Africa, CODESRIA, Dakar, 1985

Report of a Commonwealth Consultative Group, Vulnerability: Small States in the Global Society, Commonwealth Secretariat, London, 1986

Malcolm Harper and M. F. de Jong (eds.), Financing Small Enterprise, IT Publications, London, 1986

F. Lamond Tullis and W. Ladd Hollist (eds.), Food, the State, and International Political Economy, University of Nebraska Press, Lincoln and London, 1986

D. K. Fieldhouse, Black Africa 1945-1980, Allen \& Unwin, London, 1986

Ahmed Al-Shahi, Themes from Northern Sudan, Ithaca Press, London, 1986

Michael Hopkins, Alternatives to Unemployment and Underemployment, Westview Press, Boulder (Co.), 1985

The Encroaching Desert, A Report for the Independent Commission on International Humanitarian Issues, Zed Books Ltd., London, 1986

The Vanishing Forest, A Report for the Independent Commission on International Humanitarian Issues, Zed Books Ltd, London, 1986

John Davis and Alan Boliard, As though people mattered: a prospect for Britain, IT Publications, London, 1986

Eustache P. Sorocos, La morphologie sociale du Pirée à travers son évolution. Centre National des Recherches Sociales, Athens, 1985

A. Diamantopoulos and B. B. Schlegelmilch, 'A Comparison of Marketing Operations of Autonomous Subsidiaries: an empirical study', Working Paper Series no 86/8, Dept. of Business Studies, University of Edinburgh 